\title{
THE IMPLICATION OF SPECIAL PROVISIONS FOR DISPUTES OVER OWNERSHIP RIGHTS AND OTHER CIVIL DISPUTES TOWARDS RELIGIOUS COURT JURISDICTION*
}

\author{
Hartini $^{* *}$ \\ Department of Islamic Law, Faculty of Law Universitas Gadjah Mada, Yogyakarta \\ Jalan Sosio Yustisia No. 1, Bulaksumur, Yogyakarta 55281
}

\begin{abstract}
This study analyzes the meaning and scope in terms of property rights disputes or other disputes on specialis rule of clause (2) Article 50 paragraph (2) of the Law on Religious Courts and its implications to the boundary of the absolute competence between religious court and district court. This research also viewed the practice of disputes settlements deal with the property rights or other disputes on Islamic economics cases. The study was conducted by analyzing the legal regulations and court rulings related to islamic economic cases lodged property rights disputes or other disputes. Research was equipped with primary data and analyzed qualitatively.
\end{abstract}

Keywords: specialis rule, court competence, Islamic economics.

\section{Intisari}

Penelitian ini mengkaji dan menganalisis makna dan cakupan dalam istilah sengketa hak milik atau sengketa lain pada aturan spesialis, Pasal 50 ayat (2) UU Peradilan Agama beserta implikasinya terkait batas kewenangan absolut antara pengadilan agama dengan pengadilan negeri serta praktik penyelesaian sengketa hak milik atau sengketa lain yang selama ini diputus terkait perkara ekonomi syariah. Penelitian dilakukan dengan menganalisis peraturan hukum dan putusan pengadilan terkait perkara ekonomi syariah yang tersangkut sengketa hak milik atau sengketa lain. Penelitian dilengkapi dengan data primer yang selanjutnya dilakukan analisis secara deskriptif kualitatif.

Kata Kunci: aturan specialis, kewenangan pengadilan, ekonomi syariah.

\section{Pokok Muatan}

A. Background 340

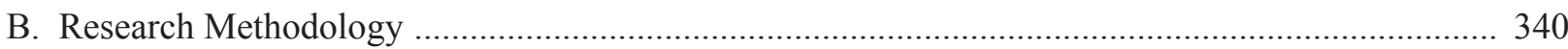

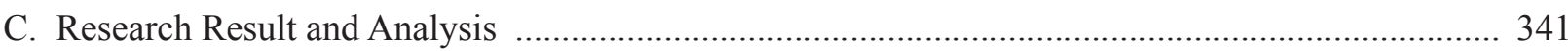

1. The Meaning and Scope of "Ownership Right Disputes" and "Other Disputes" in Law of Religious Court

2. The Competence of Religious Court to Examine Ownership Rights Disputes or Other Disputes

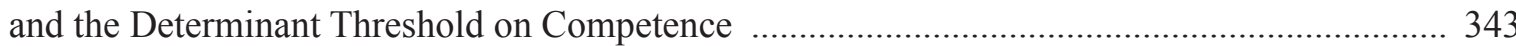

3. Settlement of Ownership Right Disputes and Other Disputes in Practice ................................... 346

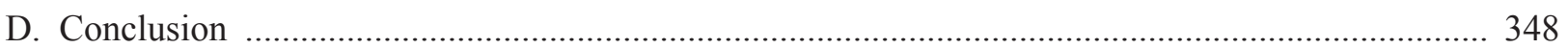

** Result of research under Unit of Research and Community Faculty of Law, Universitas Gadjah Mada, Yogyakarta in 2013.
Correspondence address: hartini@gadjahmada.edu 


\section{A. Background}

Along with the amendments of Law on Religious Court from Law Number 7 of 1989 to Law Number 3 of 2006, a change was made by the addition of a provision with a specialis character to Article 50 of Law Number 3 of 2006 to complement existing regulations relating to the settlement of ownership rights disputes or other disputes. The addition is intended to overcome one of the obstacles in the implementation of the authority of the Religious Court as well as an effort to hasten court proceeding. As an illustration, the aforementioned change in the articles is seen in the following table:

Table 1.

Comparison on Changes Made to Article 50 of Law Number 7 of 1989 to Law Number 3 of 2006

\begin{tabular}{|c|c|}
\hline $\begin{array}{c}\text { Law Number } \\
7 \text { of } 1989\end{array}$ & Law Number 3 of 2006 \\
\hline Article 50 & Article 50 \\
\hline $\begin{array}{l}\text { In the event of a } \\
\text { dispute regarding } \\
\text { ownership rights } \\
\text { and other disputes } \\
\text { in disputes as } \\
\text { referred by Article } \\
49 \text {, the specific } \\
\text { object of the } \\
\text { dispute must have } \\
\text { been previously be } \\
\text { decided by a court } \\
\text { within the General } \\
\text { Court system. }\end{array}$ & $\begin{array}{l}\text { (1) In the event of a dispute } \\
\text { of ownership rights } \\
\text { and other disputes } \\
\text { in disputes as referred } \\
\text { by Article 49, the } \\
\text { specific object of the } \\
\text { dispute must have been } \\
\text { previously be decided } \\
\text { by a court within the } \\
\text { General Court system. } \\
\text { (2) Should the ownership } \\
\text { rights dispute as re- } \\
\text { ferred to in paragraph } \\
\text { (1) occur between Mu- } \\
\text { slims, the object of dis- } \\
\text { pute is settled by Reli- } \\
\text { gious Court alongside } \\
\text { the dispute as referred } \\
\text { to in Article } 49 \text {. }\end{array}$ \\
\hline
\end{tabular}

Source: analyzed by author.

Changes and additions to the rules of settlement of disputes regarding property rights or other civil matters (in accordance to of Article 50 of Law No. 7 of 1989) into two paragraphs of Article 50 of Law No. 3 of 2006, with reductive change to ownership dispute or other disputes (paragraph (1)), and followed by a specialis rule on paragraph (2), have shifted the pattern of relation between Religious Court and General Court with regard to the settlement of ownership rights and other disputes. The attribution of object of dispute to specific a legal subject, which is Muslims (paragraph 2 Article 50) has provided an opportunity to Religious Court to settle ownership right dispute and other disputes in what was once the exclusive jurisdiction of General Court. However, the article lacks an explanation on what is meant by "ownership right disputes" or "other disputes".

The addition of a specialis rule to Article 50 (paragraph (2) Law Number 3 of 2006) raises the issue on the extent of the authority shared between Religious Court and General Court in the settlement of ownership rights or other disputes in cases of Sharia economy, which has only been recently integrated in the jurisdiction of Religious Court. Sharia economy possesses close relationship with material laws and contracts, which in practice relate to general civil laws such as the Civil Code, the Law of Trust, and others.

The paper will discuss the meaning and scope of the term "ownership right dispute" or "other dispute" along with the implications in relation to the boundary of the absolute competency between Religious Court and General Court. Practical implementation of the terms in the settlement of dispute in sharia economy will be further discussed.

\section{B. Research Methodology}

The study is a combination of normative research and empirical jurisdictional. Questions posed in problem formulation are answered through literature research and reviews of judicial decisions on cases involving ownership right disputes or other disputes in Sharia economy, which mostly were examined and decided by courts in the General Court system. The research is equipped with primary data from expert interviews obtained through Focus Group Discussion. The aforementioned interviewees include the judges of Religious Court and District 
Court in Yogyakarta, along with judges of Surakarta District Court and civil law experts from Faculty of Law UGM. Towards the obtained data, analysis was performed in descriptive-qualitative manner.

\section{Research Result and Analysis}

1. The Meaning and Scope of "Ownership Right Disputes" and "Other Disputes" in Law of Religious Court

a. "Ownership Right Disputes" or "Other Disputes": A Definitional Dilemma

A fortiori formulation of definition is important to scientific theorization or other matters of specific importance in legal science. ${ }^{1}$ Definition is ideas (gedachteninhound) raised by a particular word if an object or person acquires a name (nomenklatur). ${ }^{2}$ In the legal field, especially in the formulation of legislation, definition has an important meaning as laws, for example, are intended to govern the behavior of the people. The law must clearly define what constitutes acceptable behaviors. When a law is passed, it generally provides boundaries on the definitions used within the law. Establishment of boundary is achieved by imparting definition on juridical terms used within the aforementioned law.

In the formulation of Law Number 7 of 1989, the term "dispute relating to ownership rights and other disputes" was neither given definition or explanation on what the term entailed. The lack of definition within Law Number 7 of 1989 did not give rise to any crucial problem considering that the jurisdiction of Religious Court was relatively limited. In general, disputes on ownership rights or other civic matters arose in relation to inheritance or joint ownership of a property, in most cases, land ownership.
Long before the enactment of the Law of Religious Court in 1989, there exists a legal principle that is already recognized by both Religious Court and General Court as one of the permanent jurisprudences based on Supreme Court Decision No. $11 \mathrm{~K} /$ AG/1979 dated on 13 December 1979. The legal principle provides: "Should a lawsuit concerning the division of inheritance also contains elements of dispute on ownership rights, the lawsuit does not fall under the jurisdiction of Religious Court, and shall fall under the jurisdiction of General Court." The legal principle was further confirmed by the Supreme Court in its Working Report participated by all aspects of the judiciary on 23-25 March 1985 in Yogyakarta. It served as a benchmark that set the boundaries of the absolute competence between Religious Court and General Court in the settlement of cases that contain disputes on ownership rights during the reign of Law Number 7 of 1989 until changes were first made through Law Number 3 of 2006 on Changes to Law Number 7 Year 1989 on Religious Court.

Problem arises when "dispute relating ownership rights or other civic matters" was changed to "dispute on ownership rights or other disputes", which was followed by the abolition of optional right in the matter of inheritance and addition of the jurisdiction of Religious Court in the field of Sharia Economy by Law Number 3 of 2006.

Similarly to Law Number 7 of 1989 , nothing in Law Number 3 of 2006 gives a definition on what constitutes "dispute on ownership rights or other disputes". The lack of definition may be the result of the sheer scope of the aspects covered in the definition of ownership rights or other disputes, thus the drafting committee of Law on Religious

JJ.H. Bruggink, 1993, Rechtsreflecties, Kluwer, the Netherlands. Diterjemahkan oleh Arief Sidharta, 2011, Refleksi tentang Hukum PengertianPengertian Dasar dalam Teori Hukum, Citra Aditya Bakti, Bandung, p. 47.

Ibid, p. 49. 
Court intentionally did not include a definition in the law itself. The lack of definition is a strength in its own right; the Law becomes flexible and adaptable by allowing itself to be widely interpreted by norms that have already existed in the society and customary law, the Civil Code, or other laws that may have regulated the aforementioned matters.

\section{b. What is Meant by "Disputes on Ownership Rights and Other Dis- putes"?}

The terms 'dispute on ownership rights' or 'other disputes' should be associated with the notion of civil disputes and the division of civil law according to doctrines. Civil dispute is defined as dispute that concerns ownership rights over properties, debts or rights arising from the debt, or other civic rights. ${ }^{3}$ Whereas, as stated by Subekti, doctrines divide civil law into private law, family law, property law and inheritance law. ${ }^{4}$ Property law govern rights one owns over a property. ${ }^{5}$ Rights that fall under the jurisdiction of property law possess economic or monetary value. ${ }^{6}$ The rights themselves may be absolute or relative. Absolute property rights compel every person to respect the owner of the property. Absolute property rights are classified based on the tangibility of the object: material and immaterial. J. Satrio exemplifies ownership rights, liens and mortgage right as manifestation of rights over material object. ${ }^{7}$ Rights over immaterial objects are similarly absolute in nature, however they manifest as property rights. According to J. Satrio, distinction lies in the rule that govern respective rights; while the absolute right over properties are governed by Book II of the
Civil Code,${ }^{8}$ rights over immaterial objects are governed by its own law separate from the Civil Code. Referring to the aforementioned analysis, the definition of ownership rights dispute and other disputes will relate to rights over property possessing economic values and rights arising henceforth.

Ownership rights dispute or other disputes generally relate to property law. The term of 'property' is often synonymous to wealth or tenure. Among numerous definitions of 'property', Sri Soedewi Asjchoen S. states that:

Objects are tangible goods that may be perceived by the five senses, which includes immaterial objects. Therefore 'property' is legally defined as objects that may become the object of property and ownership rights. ${ }^{9}$

Meanwhile Subekti defined 'property' narrowly and widely. The narrow definition of 'property' only includes visually observable objects, whereas the wide definition includes any object towards which a right may be applied (object of the law). ${ }^{10}$

In general, ownership rights are governed by Book II of the Civil Code. Article 570 determines the meaning of ownership rights as well as the limitations to the exercise of ownership rights.

Ownership rights guarantee that the owner of a property may wholly own and derive enjoyment from the property that they possess, so long that the use of the property contradicts neither the law nor general rules held by the authority in possession of the right. Nor the use of the property may infringe the rights of others. Nevertheless, ownership rights may

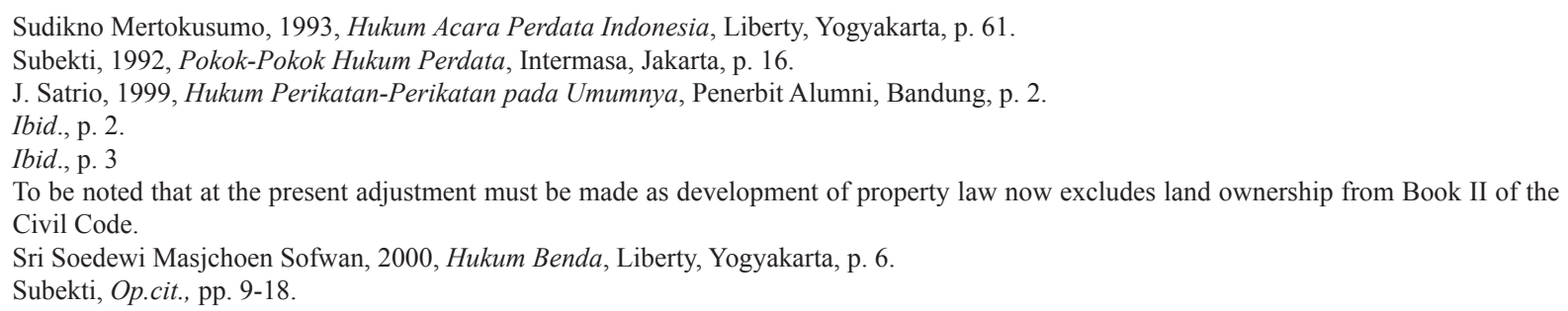


be limited by public interest; the misuse of a property may result in fair compensation according to the law. ${ }^{11}$

Law Number 5 of 1960 on Basic Rules of Agrarian Law separated ownership rights that relates to the ownership of land from the governance of Book II of the Civil Code. Ownership rights over land became the object of Agrarian Law and its previous link towards civil matters was severed. ${ }^{12}$ Land ownership rights are recognized by the Agrarian Law as the right of individual to the land in their possession. According to Article 30 paragraph (1) of the Agrarian Law, land ownership is an inherited right, the strongest and fullest rights that may be possessed over land by its owner, with due regard to Article 6. Other than ownership right, Agrarian Law recognizes other kinds of rights over land. Article 16 of the Agrarian Law states that:

The rights on land as meant in Article 4, paragraph (1) include: ${ }^{13}$

1) The right of ownership;

2) The right of exploitation;

3) The right of building;

4) The right of use;

4) The right of lease;

6) The right to open a land;

7) The right to collect resources from the forest;

8) Other rights not included in the above mentioned right which shall be regulated by law and rights of a temporary nature as mentioned Article 53.

Therefore, according to the author, the definition of settlement of ownership right disputes or other disputes that is aimed by Article 50 Law Number 3 of 2006 is the settlement of ownership rights disputes or other disputes relating to property rights, which refer to rights possessing economic value that can be measured in certain nominal value, and whether the rights manifest in the form of material rights or immaterial rights. The definition is based on the fact that Article 50 mandates that the object of dispute must beforehand be decided by courts within the General Court system. It can be therefore be concluded that any dispute over matter that possesses neither economic value nor having the elements of property falls under the absolute jurisdiction of Religious Court, for example, the rights and obligations that arise from the marriage of Muslims, the legality of the marriage or the inheritance rights between Muslims.

\section{The Competence of Religious Court to Examine Ownership Rights Disputes or Other Disputes and the Determinant Threshold on Competence}

The enactment of Law Number 3 of 2006 grants Religious Court the competence to examine and decide ownership right disputes and other disputes in relation to other matter that fall under the absolute competence of Religious Court as provided by Article 49. As seen from juridical point of view, the competence of Religious Court to examine ownership right disputes and other disputes possesses a lex specialis characteristic; ${ }^{14}$ Article 50 paragraph (2) of Law Number 3 of 2006 provides that "Should the ownership rights dispute as referred to in paragraph (1) occur between Muslims, the object of dispute is settled by Religious Court alongside the dispute as referred to in Article 49." On the other hand, the competence of General Court in the settlement of dispute over ownership right is lex generalis. ${ }^{15}$ The evidence of

Boedi Harsono, 2003, Hukum Agraria Indonesia, Sejarah Pembentukan Undang-undang Pokok Agraria, Isi dan Pelaksanaannya, Djambatan, Jakarta, p. 206.

14 The term 'regulation of a specialis character' was first mentioned by Habiburrahman in one of his papers. See Habiburrahman, "KetentuanKetentuan Baru dalam UU Nomor 3 Tahun 2006", Paper, presented on Workshop dan Pelatihan Nasional Kewenangan Pengadilan Agama dalam Penyelesaian Sengketa Ekonomi Syariah, 26-27 July 2006, held by Faculty of Law Universitas Muhammadiyah Yogyakarta, Yogyakarta, 26-27 Juli 2006.

15 A. Mukti Arto, 2012, Peradilan Agama Dalam Sistem Ketatanegaraan Indonesia, Pustaka Pelajar, Yogyakarta, p. 365. 
its generalis characteristic is found in Article 50 paragraph (1) of Law Number 3 of 2006, which provides: "In the event of a dispute over ownership rights and other disputes in disputes as referred by Article 49, the specific object of the dispute must have been previously be decided by a court within the General Court system."

Explanation on Article 50 of Law Number 3 of 2006 emphasizes that the law bestows competence to Religious Court to both examine and decide upon disputes over ownership rights or other civic disputes ${ }^{16}$ regarding objects regulated by Article 49, and the disputing parties are Muslims. The law aims to avoid attempts to hinder or halt the process of settlement made by the party disadvantaged by the submission of the lawsuit to the Religious Court, by arguing that the object of dispute must be first decided by the General Court, or any other civic matter that must first be settled prior to the submission of the lawsuit to Religious Court.

The analysis leads to the conclusion that "ownership right disputes or other disputes" within Article 50 is not the subject matter, but a part of the subject matter, thus considered to be more effective as ownership rights are examined and decided by a court in the Religious Court system alongside the merit of the lawsuit, and sufficiently fulfill the principle of simplicity, efficient and affordable. However it must be borne in mind that the law is only applicable if the disputing parties are Muslims.

Conversely, should the subject submitting the dispute over ownership rights or other disputes ${ }^{17}$ is not a subject of the competence of the Religious Court, according to Article 50, the dispute in Religious Court is adjourned until the General Court has made its decision. The provision can be interpreted to mean that if the subject of the law who files the lawsuit over ownership rights and other disputes is neither under the competence of Religious Court nor a subject or party in the subject matter and merit of the lawsuit, the lawsuit which contains dispute on ownership rights and other disputes must be adjourned until the General Court decides on the dispute over ownership rights and other disputes.

However, according to Article 50, adjournment only occurs if the objecting party has submitted proof to Religious Court that the same object of dispute identical to the one already submitted to Religious Court has been submitted to General Court. Assumption is made that at the same time there exists a dispute under the competence of Religious Court, however, prior to its submission to Religious Court a lawsuit over the ownership of the property is made to General Court. In reality, third party is likely to realize that his property rights have been infringed after dispute arises between claimant and defendant. In such situation, the only option left to the third party is to exercise intervention; the third party is unlikely to fulfill the requirements provided by the law, which requires the attachment of proof in the form of letter on the registration of his lawsuit to Secretariat of State Court, which include Surat Kuasa Untuk Membayar (SKUM).

Article 50 of Law Number 3 of 2006 clearly stipulates that Religious Court now possesses the competence to examine and decide ownership rights disputes and other disputes in the matter of Sharia economy. Additionally, changes to the competence of Religious Court are strongly supported by, inter alia:

Firstly, as seen from the subject of the law whereby the law provides that it applies to "Muslims", a term that encompasses person or institution who willingly submit themselves to Islamic law regarding matters under the competence of the Religious Court in accordance to the provision of the Article (commentary to Article I Number 37 Article 49). It may be inferred that the term "Muslim" is not limited only to a person who theologically embraces Islam, but also includes any person or institution, whether Muslim or non-

16 A few inconsistencies occur in the usage of the term in Law Number 3 Year 2006. While "ownership rights dispute or other disputes" is found in Article 50, in the commentary of the Article appears the term "ownership dispute or other civic matters" and "ownership rights dispute and other civic matters".

17 The term "other civic matters" is wholly taken from commentary of Article 50 of Law Number 3 of 2006. 
Muslim, who voluntarily recognizes and submits themselves to the law (in the activity in sharia economy). Even if a dispute of ownership rights or other rights is found in the proceeding of default or other acts contrary to the law, wherein the dispute occurs between parties who have bound themselves in a contract in sharia economy, the dispute is to be settled in Religious Court (even if one of the party bound to the contract in sharia economy is not theologically Muslim).

Secondly, Book II of the Supreme Court Year 2007 and the revision of the 2010 edition relating to Guidelines to the Implementation of Task and Court Administration in Four Judicial Circles provide doctrines that are both implemented in General Court and Religious Court, inter alia, sequestration, whether performed to object owned by defendant (conservatoir beslag) or object owned by claimant (revindicatoir beslag). Sequestration may be performed under the instruction of judges of General Court and Religious Court and carried out by clerk/bailiff of General Court or Religious Court. In similar vein, comparative sequestration (vergelijkend beslag), marital sequestration (jointly owned property), seizure, execution of debt deed, execution of mortgage, execution of trusteeship, auction (general sale) as well as offers on payment in cash and consignation may be performed either in court within the General Court or the Religious Court system. It strengthens the notion that Religious Court has the competence over matters in sharia economy inside which is found a dispute on ownership rights or other disputes.

Furthermore, some measures or criteria that may be used in determining the jurisdictional boundaries and limitation between Religious Court and General Court are as follow:

Firstly, in ownership rights dispute or other disputes there must be a distinction between subject of law that is bound to a contract in an activity in sharia economy and a subject of law that is not, especially in the involvement of an intervening third party if the dispute infringes the right over property possessed by the third party. It is possible that the ownership rights or other civic rights of the third party are affected by the contract, however the third party itself is not a party to the contract. If the party submitting the ownership right dispute is nonMuslim (for example, intervenient non-Muslim), Religious Court adjourns the examination of the dispute (aan hanging) until General Court decides on the object of the dispute. Since the object of the dispute must first be decided by General Court, Article 50 paragraph (1) of Law on Religious Court applies as general provision. Adjournment only happens if the party submitting a lawsuit to ownership rights provides proof in the proceeding of Religious Court that they have registered the lawsuit over the object to General Court. Conversely, if the third party is a Muslim, the dispute can be settled in Religious Court.

Secondly, from the object of the dispute, activities in sharia economy involves property rights of movable and immovable property rights (rights relating to land ownership) and immovable property other than land or rights over movable rights, therefore they may intersect with mortgage, fiduciary, auctions, Bankruptcy and Suspension on the Payment of Debt Obligation (Penundaan Kewajiban Pembayaran Utang). Even if the related law on mortgage, fiduciary, auction and Bankruptcy and Delay on the Payment of Debt Obligations still refer to the Civil Code, the Business Code is a positive law originally meant to govern conventional economic and banking activities. Therefore, if the same principle is applied to sharia economy, Religious Court has the competence to examine and decide on the matters. Auction and Debt and the Delay on Payment of Debt Obligations require further discussion. So far, there has not been any regulation that specifically regulates the auction system for Islamic banking. In practice, the auction system refers to Regulation of Ministry of Finance Number 93/PMK.06/2010 dated 23 April 2010, and so far falls under the competence of General Court. Even so, researchers have found one case regarding a lawsuit on auction (not the auction itself), decided by a court in the Religious Court 
system, which is the Decision of Religious Court of Bogor Number 1092/PTA.Bdg. Furthermore, in the case of Bankruptcy and Delay for the Payment of Debt Obligations, both exclusively fall under the authority of Commercial Court. In that regard, Religious Court does not have the competence to examine and decide cases on Bankruptcy and Delay on Payment of Debt Obligations.

Aforementioned matters aside, as a matter of fact Article 50 of Law Number 3 of 2006 leaves issues that require further regulation, such as:

Firstly, in principle in the event of ownership rights disputes or other ciciv disputes, the object of the dispute must have been first decided by a court in the General Court system. The principle is similar to principle governing dispute contained in Law Number 7 of 1989 (the general principle, lex generalis). ${ }^{18}$ The principle is only applicable if the dispute does not fall under the competence of Religious Court, such as the matter of trade, rent and debt in accordance to the Civil Code. It must be taken into account that activities of trade and rent may also adhere to sharia law, therefore posing the question (1) even if the ownership rights disputes or other disputes are based on the Civic Code, would it be a part of the sharia banking due to the adherence to sharia law? (2) which court has the competence if the civic disputes of trade, rent and debt according to the Civil Code blend with the concept of trade (bai') and rent (al-ijarah) according to principles of sharia?

Secondly, in the event of ownership rights disputes with Muslims as the subject of the law, Religious Court may decide on the object of the dispute alongside the merit of the case that falls under its competence. In other words, it is not necessary to grant N.O decision (niet ontvankelijk) towards object of ownership rights dispute, nor the need to wait until General Court has made its decision on the object of the dispute. The regulation is more appropriately meant as a guideline to judges of Religious Court, however may not be suited as a guideline to judges of General Court. It necessitates the creation of a reciprocity theory or doctrine between the authority of Religious Court and General Court to achieve synchronization and understanding of the competence both courts possesses and the boundaries.

Thirdly, in the submission of ownership rights dispute or other disputes with numerous objects of dispute with mixed characteristics wherein a number of objects fall under the authority of Religious Court while the rest fall under the competence of General Court, the objects must be decided by the court in which jurisdiction the object fall. The objects under the competence of Religious Court must be examined by the Religious Court, and vice versa. Even if it is able to decide on the objects that fall under its competence, the Religious Court must adjourn its examination of the merit of the case until the objects that fall under the jurisdiction of General Court have been decided by General Court. Such situation may occur when a debtor becomes the client of a creditor in a conventional bank as well as a client in a sharia bank who submits the same or different collateral in both banks. In this regard, the special characteristic of Article 50 of Law Number 3 of 2006 has not significantly altered the dependency of Religious Court to General Court.

\section{Settlement of Ownership Right Disputes and Other Disputes in Practice}

Although Law Number 3 of 2006 as the first amendment to the Law on Religious Court 1989 has attempted to reduce the dependency of Religious Court to General Court by the addition of specialis regulation to Article 50 by the inclusion of paragraph (2), in reality majority of ownership rights disputes and other disputes were settled in General Court system, as seen in a few decisions in the General Court, inter alia: 
a. Difference in Interpretation of Ownership Rights Disputes and Civic Matters are Correlated to The Subject of The Law

Although the submitted demurrer argues that the District Court does not have jurisdiction to examine and decide the case as the case falls under the absolute competence of Religious Court, the demurrer of the defendant is rejected under the consideration that the claimant is not a party to a sharia contract, therefore the District Court and High Court possess the jurisdiction to adjudicate the case. Such is seen in the Judgment of High Court of Makassar No. 45/Pdt.G/2010/ PN.Mks and affirmed by Judgment of the High Court of Makassar, as quoted: "That because the Applicant does not participate in Mudharabah Agreement, Applicant is not bound by the optional clause within the agreement as the agreement is only binding to its creators (the contracting parties), therefore the demurrer of Applicant I regarding the aforementioned absolute competence shall be rejected".

b. A Tug of War of The Authority Wherein the Lawsuit is Based on Acts Contrary to The Law or Tort

In the event of ownership rights disputes and other disputes relating to sharia economy which contains elements of tort, it is assumed that the case falls under the absolute competence of the General Court. Even if the acts against the law or tort occur due to the usage of land and building as collateral to request of credit to a sharia bank, the case shall be examined and decided by the General Court. The practice and procedure remain unchanged even if ownership rights disputes and other disputes is found in the collateral, and whether the collateral is partly or wholly owned by a third party or under the possession of other heir before the division of inheritance, as seen in the Decision of
High Court of Sleman No. 122/Pdt.G/2010/ PN. Slmn and strengthened by the Judgment of the High Court of Yogyakarta No. 60/ Pdt/2011/PTY.

\section{c. The Specialis Regulation of Article 50 Paragraph 2 of Law Number 3 of 2006 is not Effective to The Implementation of The Court in The General Court System \\ Even if the party who submits lawsuit} on ownership rights or other disputes over a property or object that is used as a collateral in activities of sharia is a Muslim, when the lawsuit is submitted to the district court, the judges of district court believe that the district court has the jurisdiction to examine and adjudicate the case under the consideration that the merit of the case is acts contrary to the law, or tort, as seen in the Judgment of the High Court of East Kalimantan in Samarinda No. 08/Pdt/2013/PT.KT.Smda. It certainly is not in accordance to the stipulation of Article 50 paragraph (2) Law Number 3 of 2006, which is a lex specialis that governs the settlement of ownership rights disputes and other disputes between Muslims. The handling of the lawsuit, especially towards which court the lawsuit is first submitted, determines the effectiveness of Article 50 paragraph (2) of Law Number 3 of 2006. If the lawsuit is first submitted to General Court, the effectiveness of the law is minimal as the law does not bind General Court.

d. General Court and Commercial Court Have The Competence to Examine Disputes on Matters of Sharia Economy if The Disputes Contain Request on The Declaration of Bankruptcy or Delay on The Payment of Debt Obligations

As seen in the Judgment of District Court of Medan No. 03/Pailit/2012/PN.Niaga. Medan and affirmed by the Judgment of the Supreme Court Number 622/K/Pdt. 
Sus/2012. Another example can be found in the Judgment of the District Court of Centar Jakarta No. 07/Pailit/2011/PN.Niaga/Jkt Pst. relating to the financing of murabahah that is affirmed by the Judgment of the Supreme Court No. 725/K/Pdt.Sus/2011. In that regard, although demurrer had been submitted by one of the disputing parties relating to the absolute competence of the District Court and Commercial Court, the panel of judges rejected the demurrer. The reasoning of District Court and Commercial Court may be found in the Judgment of Commercial Court No. 07/Pailit/2011/PN.Niaga.Jkt.Pst, in essence rejecting demurrer regarding the competency of the court and declaring that the Commercial Court in the General Court system had the competence to examine and adjudicate the case a quo. Judex factie in the consideration of the law opined:

[...] nothing in the Law Number 37 of 2004 on Bankcruptcy and Delay on the Payment of Debt Obligation provides that if the agreement that binds the parties is based on musyarakah agreement, the agreement shall not adhere to the provisions of Law Number 37 of 2004. Article 303 of Law Number 37 of 2004 on Bankcruptcy and Delay on the Payment of Debt Obligation explicitly states that the Court has the authority to examine and settle request for bankcruptcy of parties bound to agreement which contains arbitration clause, insofar the debt that becomes the basis of the bankcruptcy has fulfilled the requirements as prescribed by Article 2 paragraph (1) of the Law.

e. Differing View between District Court and High Court and The Supreme Court in The Adjudication of Ownership Right Disputes or Other Disputes where The Property is Made A Collateral in Sharia Financing

Within the General Court system itself, there are differing views on the authority to adjudicate ownership disputes and other disputes in the cases of sharia economy. At one hand, the District Court and High Court state that they do not have the competence to adjudicate the matter, however the Supreme Court opines differently. The Supreme Court then overrules the previous 2 (two) decisions where District Court and High Court declared that neither has the competence to adjudicate the matter, and declare that any agreement possessing the elements of guarantee to the object of the property to the defendant or other party is invalid. Such is seen in the Judgment of the District Court of Tasikmalaya No. 03/ Pdt/Bth/2007/PN.Tsm and upheld by the Judgment of the High Court of Bandung No. 233/Pdt/2007/PT.Bdg, however overruled by the Supreme Court in the Judgment of Supreme Court Mahkamah Agung No. 334/ PK/Pdt/2011.

\section{Conclusion}

According to the discussion and analysis, the following conclusions can be drawn: Firstly, the definition of 'ownership right disputes' or 'other matters' stipulated by Article 50 of Law Number 3 of 2006 refers to disputes relating to the ownership rights over a property, which alludes to rights that possess economic value along with the rights arising henceforth. The settlement of ownership rights disputes and other disputes within the scope of Article 50 of Law Number 3 of 2006 refer to the settlement of ownership rights disputes or other disputes relating to property rights, pointing towards rights that possess economic value that can be measured by a certain amount of nominal value whether the rights themselves are material, or the rights over immaterial objects. The principle is made in accordance to Article 50, which states the relation of court competence in the General Court system. Logically speaking, in reference to the division of civil law according to doctrines, disputes in other field of law outside property law such as family law or inheritance law automatically fall under the 
absolute competence of Religious Court when the disputed matters are based on Islamic Law.

Secondly, the addition of specialis rule through Article 50 paragraph (2) of Law Number 3 of 2006 clearly stipulates that Religious Court has the competence to examine and adjudicate ownership rights disputes and other disputes in cases that fall under its competence. Specifically in the field of sharia economy, the widening definition of "between Muslims" that is understood to also include any person or institution who voluntarily submit themselves to Islamic law allows a party, who does not theologically embrace Islam, to be placed under the competence of the Religious Court.

Even so, it is a matter of high importance to determine the limit of the competence between Religious Court and General Court, inter alia, (a) the subject of the law relating to the ownership disputes and other disputes must be distinguished between the subject who is bound to Sharia contract, and the subject who is not, (b) the object of the dispute; should the object of dispute involve movable and immovable object with the possibility of interception with mortgage, fiduciary, rules on auction as well as Bankruptcy and Delay on the Payment of Debt Obligation, there will be a link between competences. With regard to mortgage and fiduciary, both may be resolved in Religious Court. On the other hand, auction, although believed that it may only be settled by General Court, in practice there has been a lawsuit on the implementation of auction submitted to a court in the Religious Court system. On the last part, regarding Bankruptcy and Delay on the Payment of Debt Obligation, it still exclusively belongs to the jurisdiction of the Commercial Court.

Thirdly, although Law Number 3 of 2006 as the first amendment to the Laws on Religious Court Year 1989 has attempted to reduce the dependence of Religious Court to General Court through the addition of a lex specialis in Article 50 through the insertion of paragraph (2), in reality majority of cases on ownership rights disputes and other disputes are still settled in General Court System as opposed to the Religious Court system.

\section{BIBLIOGRAPHY}

\section{A. Book}

Arto, A. Mukti, 2012, Peradilan Agama dalam Sistem Ketatanegaraan Indonesia, Pustaka Pelajar, Yogyakarta.

Bruggink, JJ.H.,1993, Rechtsreflecties, Kluwer, the Netherlands.

Harahap, M. Yahya, 2007, Kedudukan Kewenangan dan Acara Peradilan Agama UU Nomor 7 Tahun 1989, Sinar Grafika, Jakarta.

Harahap, M. Yahya, 2008, Hukum Acara Perdata tentang Gugatan, Persidangan, Penyitaan, Pembuktian dan Putusan Pengadilan, Sinar Grafika, Jakarta.

Harsono, Boedi, 2003, Hukum Agraria Indonesia, Sejarah Pembentukan Undang-undang Pokok Agraria, Isi dan Pelaksanaannya, Djambatan, Jakarta.

Mertokusumo, Sudikno, 1993, Hukum Acara Perdata Indonesia, Liberty, Yogyakarta.
Satrio, J., 1999, Hukum Perikatan-Perikatan pada Umumnya, Penerbit Alumni, Bandung.

Sidharta, Arif, 2011, Refleksi tentang Hukum Pengertian-Pengertian Dasar dalam Teori Hukum, Citra Aditya Bakti, Bandung.

Sofwan, Sri Soedewi Masjchoen, 2000, Hukum Benda, Liberty, Yogyakarta.

Subekti, 1992, Pokok-Pokok Hukum Perdata, Intermasa, Jakarta.

\section{B. Papper}

Habiburrahman, "Ketentuan-Ketentuan Baru Dalam UU Nomor 3 Tahun 2006", Paper, presented on Workshop dan Pelatihan Nasional Kewenangan Pengadilan Agama dalam Penyelesaian Sengketa Ekonomi Syariah, held by Faculty of Law Universitas Muhammadiyah Yogyakarta, Yogyakarta, 26-27 July 2006. 